\title{
Effect of Cyclosporine on the Relevant Biochemical Parameters in Renal Transplantation Patients in Mosul/Iraq
}

\section{Suad Yousif Alkass}

Duhok university/Faculty of Medicine/

School of Pharmacy- Clinical

Biochemistry Dept.

\section{Mohammed Fathel Hamid}

Technical Institute/ Mosul-

Pathological Analysis Dept.

\section{Shehab Ahmed Yousif}

Technical Institute/ Mosul-

Pathological Analysis Dept.

\section{Alaa Y. Mahdy Alhamadany \\ Technical Institute/ Mosul- \\ Pathological Analysis Dept.}

\section{الخلاصة}

السيكلوسبورين هو العمود الفقري لكبت المناعة في مرضى زرع الكلى. ومع ذلك، فإنه

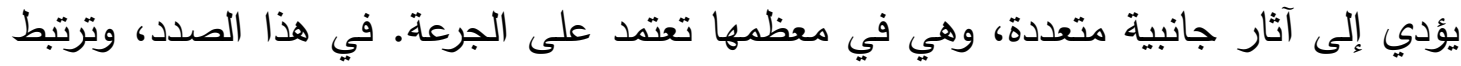

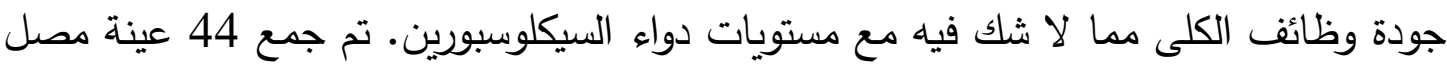

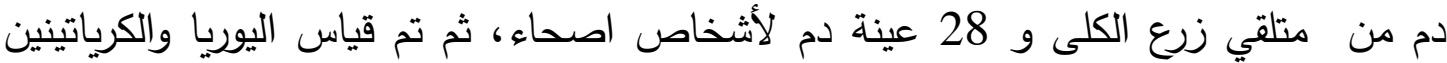

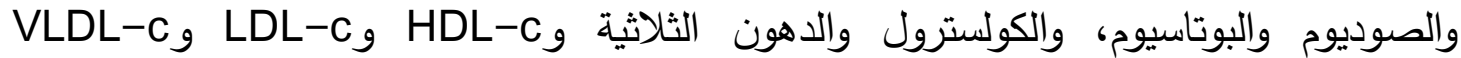
والكلوتاثيون والمالونديالدهيد في مصل الدم. أظهرت الدراسة حدوث زيادة في نسبة الكوليسترول

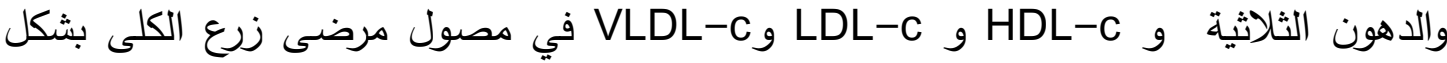

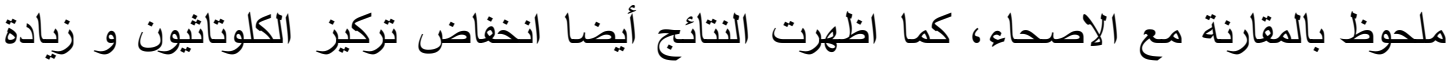

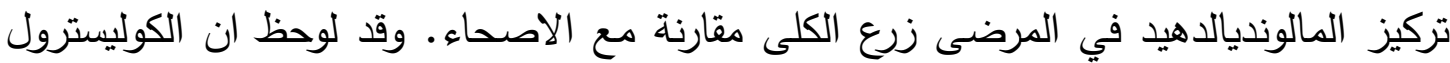

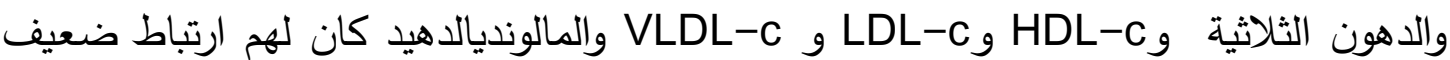

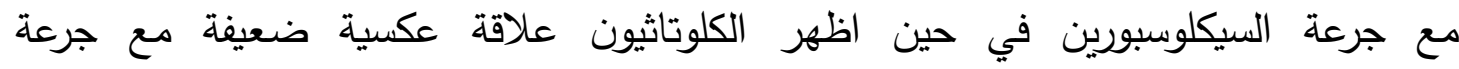

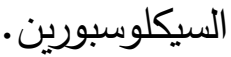
الكلمة المفتاح: زرع الكلى، السيكلوسبورين، الكلوتاثايون.

\section{ABSTRACT}

Cyclosporine (sandimmune) is the backbone of immunosuppression in renal transplantation. However, it leads to multiple side effects, most of which are dose-dependent. In this respect, the quality of renal functions is undoubtedly linked to cyclosporine drug levels.

Presented at the second conference on Chemistry, University of Mosul, college of Education, 17-18 Novamber-2013. 
Blood sample from 44 kidney-transplant recipients and 28 healthy control were collected, then serum Urea, Creatinine, Sodium $\left(\mathrm{Na}^{+}\right)$, Potassium $\left(\mathrm{K}^{+}\right)$, Cholesterol, Triglyceride, HDL-c, LDL-c, VLDL-c, Glutathione GSH and Malondialdehyde MDA were estimated. The current study showed that serum Cholesterol, TG, HDL-c, LDL-c and VLDL-c were significantly increased in renal transplantation patients comparing with the control group, The result also has been revealed that GSH concentration was decreased in renal recipient patients while MDA was increased renal recipient patients as comparing with the control group. On other hand Cholesterol, Triglyceride, HDL-c, LDL-c, VLDL-c, and MDA exhibited a weak correlation with dose of cyclosporine while GSH exhibibted reciprocal correlation with CsA dose.

Key word: renal transplantation, cyclosporine, lipid profile

\section{INTRODUCTION}

Renal transplantation is an established method of renal replacement therapy in patients with end stage renal failure ${ }^{(1)}$.

Cyclosporine A (CsA) is a powerful immunosuppressive agent which is now widely used in all organ transplantation such as the kidney and liver. The agent was marketed initially as Sandimmune (SIM) in 1984, its use has considerably improved graft and patient survival after renal transplantation $^{(2)}$. The clinical usage of CsA is however restricted due to both functional and structural changes in the kidney of transplant patients and experimental animals ${ }^{(3)}$. CsA treatment is associated with increased plasma bile acid concentrations and cholestasis in humans as well as in animal models ${ }^{(4)}$.The incidence of post-transplant hyperlipidemia has been studied primarily in patients managed on cyclosporine A (CsA)based immunosuppressive regiment ${ }^{(5)}$. Hyperlipidemia is observed in about $60 \%$ of kidney, liver, cardiac and bone marrow transplants after treatment with $\mathrm{CsA}^{(6)}$. Reported changes in serum lipid levels include elevation of triglycerides and total cholesterol. Hyperlipidemia is associated with significant morbidity and mortality rates in transplant recipients ${ }^{(7)}$. CsA-induced renal dysfunction, in turn, causes an increase in serum creatinine concentration and a decrease in creatinine clearance. These changes are dose-dependent and are usually reversible after shortterm CsA treatment ${ }^{(8)}$. Also, Antioxidants, such as $\alpha$-tocopherol, ascorbate, lazaroids, superoxide dismutase and catalase have been shown to diminish CsA-induced renal toxicity ${ }^{(9)}$. The mechanisms and the role of oxidative stress in CsA toxicity is unknown. Free radicals may be derived directly from CsA or its metabolites ${ }^{(10)}$. Some authors have found that significant increases in MDA concentration and reduced glutathione in precipitant patients in treatment of CsA ${ }^{(11,12)}$. 
The aim of the current research is to study the effect of Cyclosporine on the lipid profile and the biochemical parameters related to renal functions and show the correlation between cyclosporine and glutathione and MDA.

\section{Subjects}

\section{MATERIALS AND METHODS}

A total of 44 renal transplant patients (M: 29, F: 15) who visit IbnSina Hospital were included in this study, their ages ranged from (22-57) years, and their transplant duration ranged from( 24- 360) months . All the studied patients were under cyclosporine A (CsA) treatment with starting dose of 15.6 - $46.5 \mu \mathrm{l} / \mathrm{kg}$ body weight taken orally / day and gradually reduced according to the physician instructions. While 28 adult individuals were taken from the same population who were apparently healthy were used as a control group.

\section{Determination of renal function tests}

Serum creatinine and urea concentrations were determined colorimetrically as described by Bartles et al. (13) and Patton and Crouch $^{(14)}$, respectively, using commercially available diagnostic kits (Randox, UK; Biomerieux , France respectively).The sodium and potassium in the serum samples were analyzed using flame emission spectrophotometric method ${ }^{15}$. Briefly 1 to 100 dilution of serum was made with deionized water in universal container, mixed and aspirated into the flame analyzer at a wavelength of $589 \mathrm{~nm}$ for sodium and $765 \mathrm{~nm}$ for potassium having calibrated the machine with a standard solution containing $140 \mathrm{mmol} \mathrm{L}^{-1} \mathrm{Na}$ and $4.0 \mathrm{mmol} \mathrm{L}^{-1}$ of deionized water.

\section{Determination of lipid profile}

The lipid profile estimated from the serum was total cholesterol triglycerides, high density lipoprotein-cholesterol (HDL-c) and low density lipoprotein-cholesterol (LDL-c) after 12 hours of fasting. Total cholesterol was assayed by Tindar's reaction ${ }^{(16,17)}$ using commercial kits from Fortress Diagnostics Ltd; Antrim. Serum triglycerides level was determined as described by Fossati and Prencipe ${ }^{(18)}$, Cole et al., ${ }^{(19)}$ using commercial kit (Fortress Diagnostics Ltd; Antrim). HDL-c was determined as described by Grove, ${ }^{(20)}$ using commercial kit (Fortress Diagnostics Ltd; Antrim).

VLDL-c was calculated using the formula ${ }^{(21,22)}$ :

$\operatorname{VLDL}-\mathrm{c}(\mathrm{mmol} / \mathrm{L})=\frac{\text { Triglycerides }}{2.2}$

The serum LDL-c level was calculated according to Friedwald's formula ${ }^{(23,24)}$. 
LDL-c $(\mathrm{mmol} / \mathrm{L})=$ TCh$-(\mathrm{HDL}-\mathrm{c}+\mathrm{VLDL}-\mathrm{c})$

\section{Determination of glutathione and malondialdehyde}

Glutathione is determined in serum by utilizing Ellman`s reagent ${ }^{(25)}$. An equal volume $150 \mu 1$ of serum and $4 \%$ sulfosalicylic acid were mixed, centrifuged $(314 \mathrm{xg})$ at $4{ }^{\circ} \mathrm{C}$ for 5 minutes. To $150 \mu \mathrm{l}$ of supernatant, $4.5 \mathrm{ml}$ of $0.1 \mathrm{mmol}$ Ellman`s reagent (5,5-dithiobis 2-Nitrobenzoic acid (DTNB)) was added in phosphate buffer of $\mathrm{pH} 8.0$ (Prepared by mixing of $0.6 \mathrm{~mol} \mathrm{KH}_{2} \mathrm{PO}_{4}$ and $0.08 \mathrm{~mol} \mathrm{~K}_{2} \mathrm{HPO}_{4}$ ), then the absorbance at 412 $\mathrm{nm}$ was measured.

The level of serum MDA concentration was determined by using the method described by (Guidet, et al) ${ }^{(26)}$. To $150 \mu 1$ serum sample the following was added: $1 \mathrm{ml}$ trichloroacetic acid (TCA) $17.5 \%, 1 \mathrm{ml}$ of $0.6 \%$ thiobarbituric acid, mixed well by vortex, incubated in boiling water bath for 15 minutes, and then allowed it to be cooled (Figure 1).

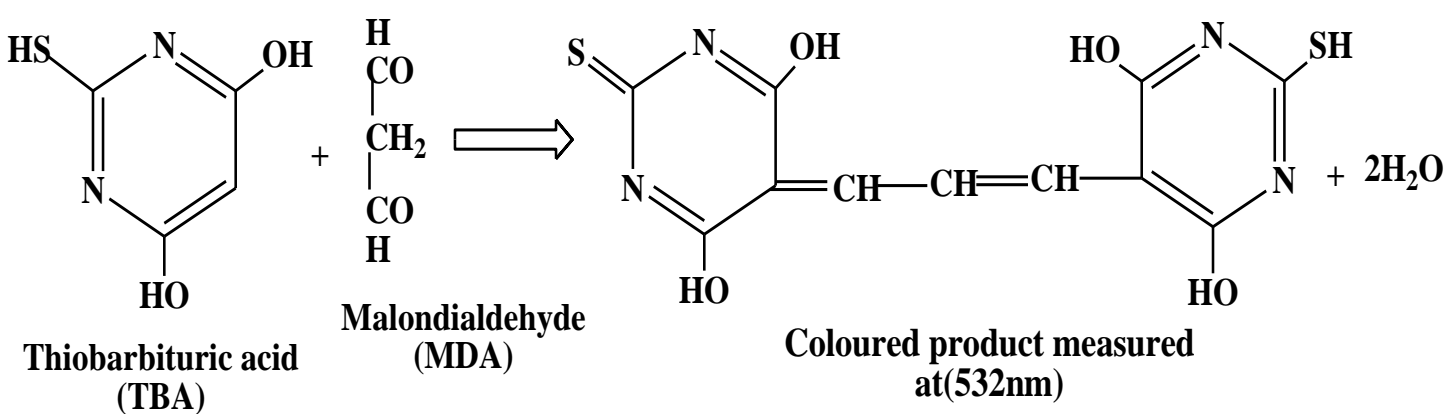

Figure (1): Reaction of malondialdehyde with thiobarbituric acid.

Then $1 \mathrm{ml}$ of $70 \%$ TCA was added, and let the mixture to stand at room temperature for 20 minutes, centrifuged at $314 \mathrm{xg}$ for 15 minutes, and the absorbance of the supernatant was measured at $532 \mathrm{~nm}$.

\section{Statistical analysis}

All data were analyzed using the statistical package for social sciences SPSS version 14 software for windows 7 . The results were expressed as mean \pm standard deviation (mean $\pm \mathrm{SD}$ ). One way ANOVA-test was used to compare parameters between dosage of CsA, malondialdehyde and GSH in different studied groups.

\section{RESULTS}

Forty four patients with renal transplant and 28 healthy controls were included in the study; the characteristics of those patients and controls are shown in Table 1. 
Effect of Cyclosporine on the Relevant Biochemical Parameters in .....

Table 1: Demographic data of the renal transplantation patients and control group

\begin{tabular}{|c|c|c|}
\hline \multirow{2}{*}{ Characteristics } & Control group & patients group \\
\cline { 2 - 3 } & Mean \pm SD & Mean \pm SD \\
\hline Age(year) & $35.14 \pm 8.59$ & $36.3 \pm 13.49$ \\
\hline Sex (male/female) & $18 / 10$ & $29 / 15$ \\
\hline Weight(kg) & $66.14 \pm 9.68$ & $69.1 \pm 9.02$ \\
\hline Dose $(\boldsymbol{\mu l} / \mathbf{k g} /$ day) & ------ & $20 \pm 6$ \\
\hline Smoking/ non smoking & $5 / 23$ & $3 / 41$ \\
\hline
\end{tabular}

Table 2 demonstrates the mean of lipid profile in renal transplantation patients and controls. Serum Total Cholesterol, TG, HDL-c, LDL-c and VLDL-c were significantly increased in renal-transplantation patient's comparing with the control group (Table 2).

Table 2: Lipid profile in renal transplantation patients and control group

\begin{tabular}{|c|c|c|}
\hline $\begin{array}{c}\text { Parameters } \\
(\mathbf{m m o l} / \mathbf{l})\end{array}$ & Control group & Patients group \\
\cline { 2 - 3 } & Mean $\pm \mathbf{S D}$ & Mean \pm SD \\
\hline TC & $4.55 \pm 0.40$ & $5.45 \pm 1.23$ \\
\hline TG & $1.42 \pm 0.28$ & $1.80 \pm 0.57$ \\
\hline HDL-c & $1.58 \pm 0.47$ & $1.35 \pm 0.47$ \\
\hline LDL-c & $2.30 \pm 0.58$ & $3.25 \pm 0.94$ \\
\hline VLDL-c & $0.64 \pm 0.15$ & $0.80 \pm 0.16$ \\
\hline
\end{tabular}

TC: Total Cholesterol, TG: Triglyceride, LDL-C: Low Density Lipoprotein- cholesterol, HDL-C: High Density Lipoprotein- cholesterol, and VLDL-C: Very Low Density Lipoprotein- cholesterol

Table 3 showed the clinical parameters of renal function tests, the results showed that serum urea, creatinine, $\mathrm{Na}^{+}$, and $\mathrm{K}^{+}$significantly increased in recipient patients comparing with control (Table 3 ).

Table 3: Renal function tests in renal transplantation patients and control group

\begin{tabular}{|c|c|c|}
\hline $\begin{array}{c}\text { Parameters } \\
(\mathbf{m m o l} / \mathbf{l})\end{array}$ & Control group & Patients group \\
\cline { 2 - 3 } & Mean $\mathbf{\text { SD }}$ & Mean $\mathbf{\text { SD }}$ \\
\hline Urea & $4.69 \pm 0.51$ & $6.54 \pm 3.38$ \\
\hline Creatinine & $96.05 \pm 11.59$ & $106.9 \pm 31.68$ \\
\hline $\mathrm{Na}^{+}$ & $140.43 \pm 1.96$ & $140.75 \pm 2.92$ \\
\hline $\mathrm{K}^{+}$ & $4.27 \pm 0.33$ & $4.29 \pm 0.50$ \\
\hline
\end{tabular}

The present study has revealed that GSH concentration was decreased $(13.42 \mu \mathrm{mol} / \mathrm{l})$ while MDA was increased in serum of renal recipient patients $(6.60 \mu \mathrm{mol} / \mathrm{l})$ as comparing with control group (18.05 $\mu \mathrm{mol} / 1)$. see Table 4.

Table 4: GSH and MDA in renal transplantation patients and control group

\begin{tabular}{|c|c|c|}
\hline $\begin{array}{c}\text { Parameters } \\
(\boldsymbol{\mu m o l} / \mathbf{l})\end{array}$ & Control group & Patients group \\
\cline { 2 - 3 } & Mean \pm SD & Mean \pm SD \\
\hline GSH & $18.05 \pm 0.46$ & $13.42 \pm 1.45$ \\
\hline MDA & $5.16 \pm 0.32$ & $6.60 \pm 0.56$ \\
\hline
\end{tabular}

GSH: Glutathione, MDA: Malondialdehyde 
Our study showed that total cholesterol, Triglyceride, HDL-c, LDLc, VLDL-c, and MDA had a weak correlation to the dose of cyclosporine (Table 7).

Table 7: dose correlation with lipid profile, GSH, and MDA

\begin{tabular}{|c|c|}
\hline Parameters & Dose \\
\hline TC & 0.049 \\
\hline TG & 0.287 \\
\hline HDL-c & 0.118 \\
\hline LDL-c & 0.054 \\
\hline VLDL-c & 0.286 \\
\hline GSH & -0.376 \\
\hline MDA & 0.098 \\
\hline
\end{tabular}

TC: Total Cholesterol, TG: Triglyceride, LDL-C: Low Density Lipoprotein- cholesterol, HDL-C: High Density Lipoprotein- cholesterol, and VLDL-C: Very Low Density Lipoprotein- cholesterol, GSH: Glutathione, MDA: Malondialdehyde

\section{DISCUSSION}

The present study highlighted the hyperlipidemia, GSH and MDA also its correlation with CsA. The overall number of patients who did their renal transplantation was higher in male than in females in our study. It has been observed that kidney function tests (Creatinine, Urea, $\mathrm{Na}^{+} \& \mathrm{~K}^{+}$) were normal comparing to control which differs from other study that showed abnormalities of the electrolytes in patients with renal trans-plantation $^{(27)}$, suggested that abnormal transport of electrolytes in renal tubules in transplant kidneys might be responsible for these electrolytes disturbances ${ }^{(28)}$. Some studies showed that CsA is associated with electrolyte disturbances; for example, long-term treatment with CsA increases the fractional excretion of sodium ${ }^{(29)}$. Also with Gado et al. ${ }^{(30)}$ who documented that the serum creatinine and urea are elevates in renaltransplantation patients, serum creatinine level was slightly increased compared to the healthy control these results are in agreement with the results of other studies conducted by Wissman et al., 1996, Moroni et al $2006^{(31,32)}$. Who found that the cyclosporine nephrotoxicity is dose dependent and the low doses of cyclosporine did not significant changes renal function. A recent study showed the existence of dyslipidemia in renal transplant patients ${ }^{(33)}$. It has been observed that lipid profile altered in transplanted patients and the levels of total cholesterol and triglyceride HDL-c, LDL-c andVLDL-c significantly increased in all patients under cyclosporine regimen as compared with healthy controls. The role of cyclosporine in post-transplant hyperlipidemia is still unclear although some workers had implicated in its causation ${ }^{(34)}$. Others indicated that, cyclosporine contributes to hypercholesterolemia in renal transplant patients ${ }^{(35)}$. In the present study, it has been reported that cyclosporine had weak correlation with lipid profile levels in agreement with other 
studies showing weak correlation between cyclosporine level and lipid profiles, suggested may due to the long duration of treatment by cyclosporine rather than its level may affect the lipid profile in posttransplant patients ${ }^{(25)}$, and could explain the discrepancy between results, on other hands disagreement with Awad et al. ${ }^{(36)}$ and Kuster et al. ${ }^{(37)}$ who reported that no correlation between TG and total cholesterol levels with cyclosporine dose. In addition, it has been observed that MDA significantly increase in renal recipients with increasing dosage that harmony with Sawicka et al. ${ }^{(11)}$ who documented that significant increase in MDA concentration after CsA doses of 450-750 ng/ml. In children after liver transplantation, CsA concentrations in plasma of $70-120 \mathrm{ng} / \mathrm{ml}$ did not cause statistically significant increases in MDA levels compared to control ${ }^{(38)}$. In research on patients with rheumatoid arthritis treated with low doses of CsA it was observed that $2.5-3.5 \mathrm{mg} / \mathrm{kg}$ b.w. of CsA did not increase MDA ${ }^{(39)}$.

Glutathione is a small peptide composed of three amino acids, (cysteine, glutamic acid and glycine). It is an important antioxidant and plays a very important role in the defense mechanism of tissues against ROS ${ }^{(40)}$. In the present study, it has been observed that GSH decreased with increasing dosage in renal recipients which compatible with Mostafavi-Pour et al., ${ }^{(41)}$ who documented that decreased in GSH levels in CsA treated patients suggested a possible direct interference of the drug with the intracellular homeostasis of glutathione ${ }^{(42)}$. Other study in rats showed that CsA had an effect on lipid peroxidation; it caused significant decrease in the antioxidant status that are GSH and catalase enzyme activity ${ }^{(43)}$.

\section{CONCLUSIONS}

In conclusion, hyperlipidemia is a common problem after renal transplantation. CsA has a weak correlation with lipid profile and MDA and it has been reciprocal relationship with GSH.

\section{REFERENCES}

1) Schnuelle P., Lorenz D., Trede M., and Van Der Woude F., Impact of renal cadaveric transplantation on survival in end-stage renal failure: Evidence for reduced mortality risk compared with hemodialysis during long-term follow up. J Am Soc Nephrol., 9 (11): 2135-2141 (1998).

2) Nampoory M., Johny K., Costandi J., Al Muzaire R. A., Gupta R., and Nair M.P., Cyclosporine neoral: a Local experience. Saudi J Kidney Dis Transpl.,10 (1):26-30 (1999). 
3) Naidu M., Kumar J.V., Shifow A.A., Prayag A., and Ratnakar K., Lacidipine protects against cyclosporine induced nephrotoxicity in rats. Nephron, 81: 60-66 (1999).

4) Deters M., Kirchner G., Koal T., Resch K., and Kaever V., Everolimus/cyclosporine interactions on bile flow and biliary excretion of bile salts and cholesterol in rats. Dig Dis Sci., 49: 30-37 (2004).

5) Ballantyne C., Podet E., Patsch W., et al., Effects of cyclosporine therapy on plasma lipoprotein levels. JAMA, 262 (1):35-56(1989).

6) Miller L.W., Cardiovascular toxicities of immunosuppressive agents. Am J Transplant, 2: 807-818 (2002).

7) Toussaint C., Kinnaert P., and Vereerstraeten P., Late mortality and morbidity five to eighteen years after kidney transplantation. Transplantation, 45: 554-558 (1988).

8) Andoh T.F., and Bennett W., Chronic cyclosporine nephrotoxicity. Curr Opin Nephrol Hypertens, 7:265-270 (1998).

9) Wang C., and Salahudeen A., Cyclosporine nephrotoxicity attenuation by antioxidant-inhibitor of lipid peroxidation in vitro and in vivo. Transplantation, 58:940-946 (1994).

10) Buetler T., Cottet-Maire F., Krauskopf A., and Ruegg U., Does cyclosporin A generate free radicals? Trends Pharmacol Sci 21:288-290 (2000).

11) Sawicka E., Długosz A., and Przybylska D., The Effect of Cyclosporin A on Free Radical Processes and Interactions with Antioxidants. Adv Clin Exp Med., 15( 3): 435-444 (2006).

12) Akbasli A., Keven K., Erbay B., Nebioglu S., Changes in oxidative stress in renal graft patients receiving calcineurin inhibitors: cyclosporine versus tacrolimus. Exp Clin Transplant,10 (5):439445(2012).

13) Bartles H., Bohmer M., and Heieri C., Serum kreatininbestimmung ohne Enteiweissen. Clin Chim Acta., 37: 193-197(1972).

14) Patton C., and Crouch S., Spectrophotometric and kinetics investigation of the Berthelot reaction for the determination of ammonia. Anal Chem., 49: 464-9 (1977).

15) Tietz N., Pruden, L., and Andersen S., Electrolytes, In: Tietz Fundamentals of clinical Chemistry, Tietz, N.W. (Eds.) 2nd Edn. W.B. Saunders Co., Philadelphia, USA., pp: 712-738 (1996).

16) Evans A., and Stein M., Lipids, lipoproteins and apolipoproteins: In: Textbook of Clinical Chemistry (Tietz, W.W. ed) W.H. Saunders Co. Philadelphia, pp. 884-887(1986).

17) NIH. : National Institute of Health. Recommendations for Improving Cholesterol Measurement, A Report from the Lab. Standardization 
Panel of the National Cholesterol Education Programme. NH Publication No. 90-2564 (1990).

18) Fossati P., and Prencipe L., Serum triglycerides determined colorimetrically with an enzyme that produces hydrogen peroxide. Clin. chem., 28:2077- 2080(1982).

19) Cole T.G., Klotzsch S.G., McNamara J. Measurement of triglyceride concentration. In: Rifai N., Warnick G.R., Dominiczak M.H., eds. Handbook of lipoprotein testing. Washington: AACC Press, 115-126 (1997).

20) Grove H., Effect of reagent $\mathrm{pH}$ on determination of high density lipoprotein cholesterol by precipitation with sodium phosphatungstatemagnesium. Clin. Chem. 25: 560-564(1970).

21) Henry J., Clinical Chemistry, In: Clinical and Diagnosis Management by Laboratory Methods. 18thi ed. W.B. Saunders com. London, UK. pp. 189-214 (1991).

22) Satheesh M., and Paris L., Effect of pterostilbene on lipids and lipid profiles in streptozocin-nicotinarnide induced type 2 diabetes mellitus. J. Apl. Biomed. 6:31-37(2008).

23) Friedwald W., Levy R., and Fredrickson D., Estimation of the concentration of low density lipoproteincholesterol in plasma without use of the preparative ultracentrifuge. Clin. Chem., 18 (6): 499-502 (1972).

24) Sood R., Textbook of Medical Laboratory Technology. Jaypee Brothers Medical Publishers (p) New Delhi, pp.609-671(2006).

25) Sedlak J., Lindsay R., Anal. Biochem.192.Cited by Al-Zamely O., Al-Nimer M., Al-Muslih R., (2001). Detection the level of peroxynitrite and related with antioxidant satus in the serum of pateints with acute myocardial infarction.Nation. J.Chem., 4:625637(1968).

26) Guidet B., Shah S., Am. J. Physiol. 257(26):F440. Cited by Muslih, R. K., Al- Nimer, M. S., Al-Zamely, O. M.(2002). The level of malondialdehyde after activiation with $\left(\mathrm{H}_{2} \mathrm{O}_{2}\right.$ and $\left.\mathrm{CuSO}_{4}\right)$ and inhibition by desferoxamine and molsidomine in the serum of patients with acute myocardial infarction. Nation. J. Chem. 5:139148(1989).

27) Melnikov S., Mayan H., Uchida S., Holtzman E., and Farfel Z., Cyclosporine metabolic side effects: association with the WNK4 system. Eur J Clin Invest., 41(10): 1113-1120( 2011).

28) Tekgündüz E., ApaydIn S., Seyahi N., and AltIparmak M., Electrolyte Free Water Clearance Could Be an Early Sign of Renal 
Dysfunction in Renal Transplant Patients. Transplantation Proceedings. 41(9):3726-3730(2009).

29) Wang J., Zhang Z., Chou C., Liang, Y., Gu Y., and Ma H., Cyclosporine stimulates the renal epithelial sodium channel by elevating cholesterol. Am J Physiol Renal Physiol., 296(2):F284290(2009).

30) Gado A., Abdel N., and Badr A., Protective Effect of Lycopene against Nephrotoxicity Induced by Cyclosporine in Rats. Life Science Journal. 10(2) (2013). http://www.lifesciencesite.com

31) Wissmann C., Felix J., Ferrari P., and Uehlinger D., (1996) .Acute cyclosporine- induced nephrotoxicity in renal transplant recipients: the role of the transplanted kidney. Journal of the American Society of Nephrology, 7 :2677-2681.

32) Moroni G., Doria A., and Mosca . et al ., (2006).A randomized pilot trial comparing cyclosporine and azathiopine for maintenance therapy in diffuse lupus nephritis over four years . Clin. J. Am. Soc. Nephrol, 1:925-932.

33) Suleiman B., El Imam M., Elsabigh M., Eltahir K., Eltahir A., and Miskeen E., ipid Profile in post-transplant renal patients treated with Cyclosporine in Sudan, Saudi J Kidney Dis Transpl., 20 (2),312-317 (2009).

34) Raine A.., and Morris P., Hyperlipidemia after renal transplantation. Lancer., 2:391(1988).

35) Markell M., Brown C., and Butt K., Prospective evaluation of changes in lipid profiles in cyclosporine treated renal transplant patients. Transplant Proc., 21:1497-9 (1989).

36) Awad R., Omar A., Mostafa T., et al., Hypercholesterolemia in renal transplant recipients; Contributing factors, effect of dietary modification and fluvastatin therapy. Saudi J Kidney Dis Transpl., 10(2):148-51 (1999).

37) Kuster G., Drexel H., Blesch J., et al., Relation of cyclosporine blood levels to adverse effects on lipoproteins. Transplantation. 57:1479-83 (1994).

38) Granot E., Shemesh L., Rivkin L., and Kohen R., Plasma and low-density lipoprotein lipid peroxidation in cyclosporine A treated children after liver transplant. Transplant Proc., 30, 4057-4059 (1998).

39) Wang C., and Salahudeen A., Lipid peroxidation accompanies cyclosporine nephrotoxicity: Effect of vitamin E. Kidney Int., 47, 927-934 (1995).

40) Ray S., Panditb B., Dasb S., and Chakraborty S., Cyclophosphamide -Induced Lipid Peroxidation and Changes in 
Cholesterol Content: Protective Role of Reduced Glutathione. Iran J Pharm Sci.,7(4) (2011).

41) Mostafavi-Pour Z., Khademi F., Zal F., Sardarian A., and Amini F., In vitro analysis of csa-induced hepatotoxicity in hepg2 cell line: oxidative stress and $\alpha 2$ and $\beta 1$ integrin subunits expression. Hepatitis Monthly; 13(8): e11447(2013).

42) Burdmann E., Andoh T., and Yu L., Bennett W., Cyclosporine nephrotoxicity. Semin Nephrol ., 23: 465-476 (2003).

43) Al-Amran F., Hadi N., Kamoona T., and Kadhum Z., Amelioration of chronic cyclosporine a-induced nephrotoxicity by telmisartan in rats. African Journal of Pharmacy and Pharmacology Vol. 5(4), pp. 500-505(2011). 